\title{
REPORT ON THE COURSE OF STUDY BZ-1003-BR FOLLOWING THE CHANGES IN AIRWAYS IN STUTTERERS WITH THE HELP OF PULSE OSCILLOMETRY (MASTER SCREEN IOS)
}

\author{
Josef Pešák ${ }^{1}$, Tomáš Grézll, Ludmila Hurtová ${ }^{1}$, Lenka Modráčková ${ }^{2}$ and working group*
}

Palacky University in Olomouc, Medical Faculty, Czech Republic: Institute of Medical Biophysics'; Palacky University in Olomouc, Faculty of Education, Czech Republic: Department of Musical Education ${ }^{2}$

*Dagmar Vodičková, Zlín; Zdeňka Skeřilová, Ostrava; Dagmar Pluháčková, Břeclav; Renata Rokytová, Kroměříž; Dana Popelářová, Staré Město u Uherského Hradiště; Marcela Kozáková, Prostějov

Summary: Stuttering affects people all over the world. At the age of six years, about 1.5 percent of children suffers from stuttering. Although stuttering resolves spontaneously upon reaching adulthood in approximately $80 \%$ of those affected, it continues to have significant health and social consequences. So far, its etiology remains unknown. The organic differences in those with stuttering and those free of speech problems have been evaluated. As a result of these examinations, it has been hypothesized that stuttering results from functional pneumoobstruction of the tracheobronchial tree in the peripheral respiratory passages. As for now, no similar therapeutic procedure, using a bronchodilating agent in the treatment of stuttering, has been described. Preliminary findings of a pilot study $(15,16)$ are surprisingly positive. In October of 2003, a multicenter open clinical trial (Stage III) to verify the effect of a sympathomimetic agent formoterol was initiated. The study is being realized in six centers in Moravia and enrolls approx. 40 patients (children, adolescents and young adults). First experience and initial evaluation of the cohort are presented here.

Key words: Stuttering; Bronchodilatation; Pulse oscillometry

\section{Introduction}

Stuttering is a very sad problem for people affected by this speech impediment. We can mention that the evidence of this handicap has been known for more than 4 millenniums. This is an important reference for following connections and links associated with stuttering on time axis backward. The second interest is the information that localizes areal occurrence of the most various names for stammering. Richard Kitchen and Van Riper (1) in their work The Nature of Stuttering (1982) gathered up the marks for stammer virtually all over the world:

- in Europe near 21 nationalities,

- in the East near 15 state formations, from which entirely of 11 languages at Indians,

- in Africa near 10 nationalities,

- on American continent in 4 regions, from which only at original inhabitants - at 11 American-Indian tribes and

- in Pacific in 3 insular territories.

From the etymological point of view are all these expressions synonyms of the substantive stuttering (that is in a quantity of 75) of miscellaneous onomatopoeic appellations. For instance: Czech word koktat (to stammer) means to pronounce ko-ko-ko, as a comparison to kohout (a cock). (Kohout - in old Czech kohút - has Slavonic onomatopoeic basis ko-ko, which means cock that is gathering his hens.) (2).

Altogether they are primitive imitations of iterative utterance when the speech fluency is disturbed by stammer.

Stammer is a noticeable speech and communication impediment that occurs in time and place and that is so general that there is an assumption that the cause of this disorder could be also one of the most general. Proportionally to the previous supposition, there is a possible general biophysical interpretation (3) that was later presented at neurological forum (4) and afterward even at The Department of Respiratory Diseases and Tuberculosis, Teaching Hospital in Olomouc (5). Hypothetical etymology of the word stuttering was published in Medical Hypotheses (6). Subsequently, other reports were published $(7,8,9)$.

On the basis of the Paediatric clinic seminar with the main topic called „children and teenage stammering“, there 
was a block of the lectures about children speech disorders on $\mathrm{XXI}^{\text {st }}$ Days of Clinical and Practical Paediatrics, part of which was an information about stuttering (10). In presented note and in the following performances there were reports about the first experience with stammer therapy $(11,12)$.

On the basis of previous findings, a clinical trial was proposed and approved by the Ethics Committee of the Teaching Hospital and the Faculty of Medicine, Palacký Unversity, Olomouc (13). The company ZAK-PharmaServices s.r.o. prepared the final protocol of the study evaluating the effectiveness and safety of a sympathomimetic agent formoterol in the alleviation of speech non-fluency (14).

The aim of the present contribution is to refer on the clinical study project and methods; the results, both preliminary and final ones, will be reported later.

Present description of therapy with the assistance of bronchodilatation after more than one year of usage of formoterol in the case of the same female subject ( 13 years) as in previous citations $(10,11)$ is given in reports $(15)$ and (16).

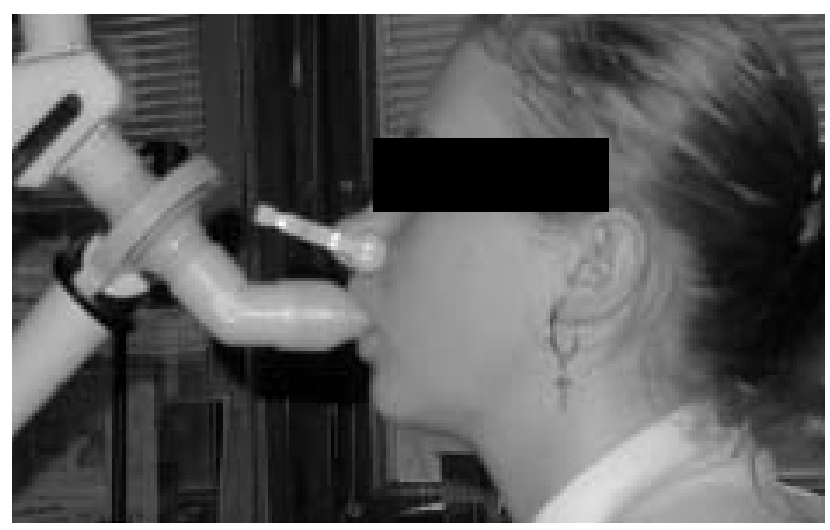

Fig. 1. Detailed view of spirometric investigation.

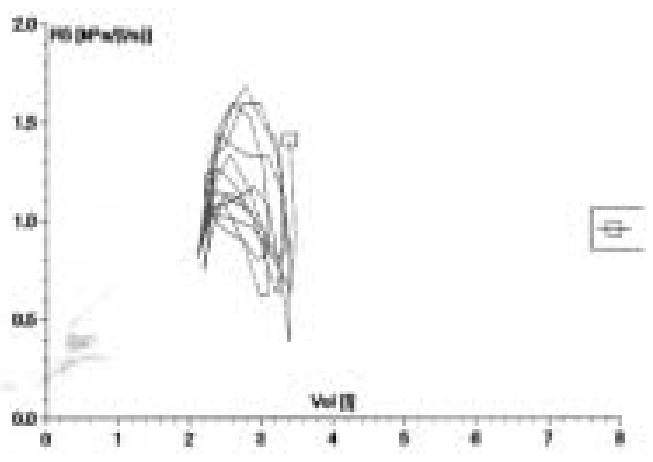

Fig. 3. Entry of the instance of resistance in upper airways of a stuttering subject.

\section{Material and methods}

Protocol (14) defines the Teaching Hospital in Olomouc as the central specialized facility. Evaluation of the treatment will involve initial biochemical test, neurological tests EEG and EMG. Further on, test of heart rate variability VSF by the VarCor PF-5 instrument and the speech records of chosen subjects, and spirometric tests with the assistance of instrument MasterScreen IOS (specific functional parameters of lung - rate of flow volume and peripheral limitations of small airways) will be performed. The program of impulse oscillometry IOS provides a reliable analysis of pulmonary distribution disorders, including impairment of the mechanics of breathing. Graphic presentation modelling the lungs gives a rapid overview of the level of pulmonary functions. The respiratory flow is superposed by short-term test impulses. Accurate measuring of flow signal together with resulting response of pulmothoracic pressure brings about the respiratory impedance. Impulse oscillometry is a most useful tool for differential diagnostics of diseases of pulmothoracic system. It is highly sensitive in registering peripheral limitation of respiratory tract, instability

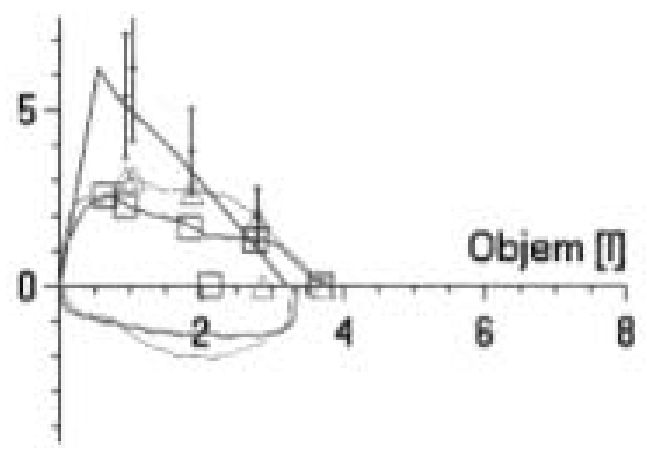

Fig. 2. Entry of the instance of discharge measurement of the volume in a stutterer.

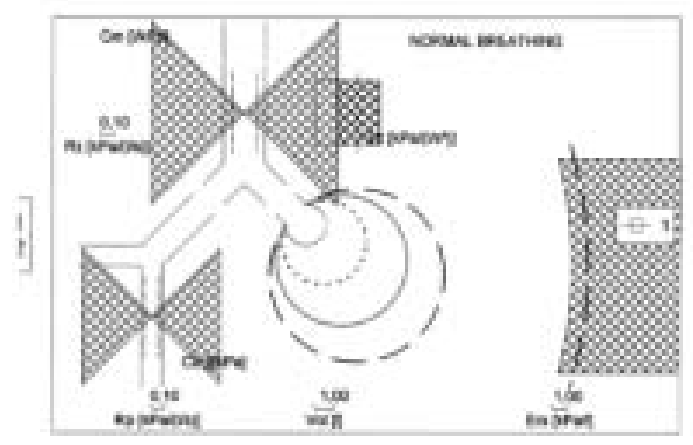

Fig. 4. Entry of the instance of registration of obstructions in airways. 
of bronchial tract (air trapping) as well as in determination and differentiation of extrathoracic stenosis. Its sensitivity makes it able to register even the changes considered as physiological from the respiratory point of view, but typical for subjects suffering from the speech fluency disorders.

Figure 1 presents a detailed view of spirometric investigation. Above mouthpiece in top part above trapezoidal tesserae, outer generator equipment Master Screen IOS is fixed. Following figures show examples of investigation records. Fig. 2 a flow volume, Fig. 3 retrained, incarcerates air in small airways, and Fig. 4 an illustrative entry of obstructions in airways.

Number of experimental centres finally stabilized at 6 . They are localized in six Moravian towns from Břeclav to Ostrava. The first test was realized on November $11^{\text {th }}$ and on February $25^{\text {th }}$ we decided to finish entrance test with the number of 42 surveyed subjects. New centres were opened after above mentioned entrance tests in experimental centres by a monitor (ZAK-PharmaServices). The process of opening the therapy in separate centres continues while the first patients are almost ready for the second visit in these centres, as it has been supposed in The Scheme of the study progress. These time periods between particular visits in the centres happen due to the consumption of 60 Foradil $^{\circledR}$ capsules with the minimal dose of formoterol $12 \mu \mathrm{g} /$ capsule.

Subjects were chosen by physicians with specialization in phoniatrics (co-authors of the contribution) in six centres of the opening multicentric study BZ-1003-BR. According to the age, group I involved 28 boys $(\overline{\mathrm{x}}=11.357$ years, $\mathrm{s}=$ 2.683 years $)$ and 8 girls $(\overline{\mathrm{x}}=13.625, \mathrm{~s}=3.248$ years $)$ and group II (18-25 years) consisted of 5 men $(\overline{\mathrm{x}}=21.5$ years, $\mathrm{s}=2.683)$ and 2 women $(\overline{\mathrm{x}}=19.5, \mathrm{~s}=2.18$ years $)$. Spirometric investigation was effected by pulsed oscillometer Master Screen IOS Kurka Jaeger. Then the investigation of flow-volume and inconstancy of bronchial organism was performed. (Air trapping - incarcerate air in small airways), as well as the spirometric investigation at 43 stutterers. This investigation also followed 1) "voluminous" position $\mathrm{V}$ of peak-flow at expiration PEFR, 2) peripheral limitation of inspiratory tract by IOS method, 3) central $\mathrm{Rz}$ and peripheral $\mathrm{Rp}$ resistance of the airways, 4) positions of characteristic waveforms of general inspiratory speed R5 and distal capacitance X5. All monitored values exceeded tolerance limits. Tetanic syndrome was discovered during the investigation in 37 subjects $(86 \%)$.

\section{Conclusion}

Pathological findings at monitored inspiratory functions were registered in 43 observed stuttering subjects.
One patient (female, 21 years) had to be excluded from the study due to increased parameters THS $(8.128 \mathrm{mU} / 1-$ physiol. range 0.35-5.5) and T3 (FT3) (7.06 pmol/1 - physiol. range $3.54-6.47$ ).

\section{References}

1. htpt://mankato.msus.edu/dept/comdis/kuster/words.html

2. Holub J, Leyer S. Stručný etymologický slovník jazyka českého. Praha: SPN, 1978.

3. Pešák J. Balbuties, vada řeči \& biofyzikální hypotéza její neznámé etiologie. In: Rosina J, ed. Sborník abstrakt XXIV. Dny lékařské biofyziky, konference s mezinárodní účastí. Praha: Ústav lékařské biofyziky UK, 2001.

4. Pešák J, Bartek J, Zatloukal J. Neuropatofyziologický pneumoobstrukčni faktor u balbuties. In: Kuchár M, ed. 48. Společný zjazd slovenskej a českej společnosti pre klinickú neurológiu. Nové Zámky, 2001.

5. Pešák J. Hypotetický pohled na etiologii balbuties. Odborný semináŕ Kliniky TBC a respiračních nemocí, Klinika plicních nemocí a TBC, LF UP a FNO v Olomouci, Olomouc 5. 12. 2001.

6. Pešák J. Pneumoobstruction of the tracheobronchial tree as a hypothetical cause of balbuties. Medical Hypotheses 2002;59(4):458-61.

7. Pešák J, ed. Hypotéza pneumoobstrukční etiologie koktavosti. In: Sborník přednášek 9. semináře univerzitního Společenství pro studium hlasu a řeči. Olomouc: Ústav lékařské biofyziky LF UP v Olomouci, 2002.

8. Pešák J. Hypotéza pneumoobstrukční etiologie koktavosti. In: Dlouhá O, Laštovka M, eds. Novinky ve foniatrii 2002. Praha: Galén, 2002.

9. Pešák J. Koktavost, balbuties: K popisu současné situace. In: Pešák J, ed. Sborník přednášek SEMINÁŘE DĚTSKÉ KLINIKY s hlavním tématem „,balbuties, koktavost u dětí a mladistvých”. Olomouc: Ústav lékařské biofyziky LF UP v Olomouci, 2003.

10. Pešák J, Maňásková E. Koktavost. Pediatrie pro praxi 2003;4(3):171.

11. Pešák J. Primární experiment klinického zmírňování (odstraňování) neplynulosti řeči u dětí a mladistvých s balbuties. In: Pellant A, Chrobok V, eds. Sborník abstrakt 66. kongresu České společnosti otolaryngologie a chirurgie hlavy a krku ČLS JEP s mezinárodni účastí $k$ př́ležitosti 100 let založení Nemocnice Pardubice. Hradec Králové: NUCLEUS HK, 2003.

12. Pešák J. Ověřování klinického odstraňování (zmírňováni) neplynulosti řeči u dětí a mladistvých s balbuties. In: Lejska M, ed. Sborník 1. česko-slovenského foniatrického kongresu a XIV. celostátních foniatrických dnů Evy Sedláčkové, Brno: Audio-Fon Centr s.r.o., 2003.

13. Rozhodnutí Etické komise Fakultní nemocnice a Lékařské fakulty UP v Olomouci, čj. 46/03. Ověřování klinického odstraňování (zmírňování) neplynulosti řeči u dětí a mladistvých s balbuties. Olomouc 2003.

14. Protokol: BZ-1003-BR Ověřování vlivu bronchodilatace na plynulost řeči u nezletilých i dospělých s balbuties, Součást výzkumného záměru MSM 152100018, ZAK-Pharma Services s.r.o., Finální verze 03.11.03, Brno 2003.

15. Pešák J. Zmírñování zadrhávání $\mathrm{v}$ řeči u dětí a mladistvých s balbuties po aplikaci $\beta_{2}$ sympatomimetika formoterol. Klin Farmakol Farm 2004;18(1): $19-20$.

16. Pešák J. Preliminary experience with formoterol for the treatment of stuttering. Letter to the Editor. Ann Pharmacother 2004;38(7-8):1323.

Prepared under the sponsorship of the research task MSM 152100018 "Integrated study of voice and speech”.

\author{
Doc. RNDr. Josef Pešák, CSc., \\ Palacky University Olomouc, \\ Faculty of Medicine, \\ Institute of Biophysics, \\ Hněvotínská 3, 77515 Olomouc, \\ Czech Republic. \\ e-mail:pesak@tunw.upol.cz
}

